Mirosław Pawlak

Uniwersytet im. Adama Mickiewicza w Kaliszu

Państwowa Wyższa Szkoła Zawodowa w Koninie

pawlakmi@amu.edu.pl

\title{
STUDIA FILOLOGICZNE, PRZYGOTOWANIE DO ZAWODU NAUCZYCIELA A WYZWANIA CODZIENNOŚCI
}

\author{
Foreign language programs, teacher preparation \\ and everyday challenges
}

Becoming a foreign language teacher involves meeting a range of requirements which have mainly been specified in the Decree of the Minister for Science and Higher Education issued on January $17^{\text {th }}, 2012$, concerning the standards that have to be complied with in teacher education. Education of this kind is still most frequently offered in the course of BA or MA programs in foreign languages, with the crucial caveat that, primarily as a result of decreasing demand for foreign language teachers, this component has been eliminated in many institutions of higher education or students are required to pay for an additional module providing such training. It is assumed that on completion of a BA or MA program as well as obtaining credits for the required courses focusing on pedagogy, a student will have the requisite qualifications to teach a particular foreign language at appropriate educational levels. This implies that, by this time, he or she should have acquired the necessary knowledge, skills and competences, both in the foreign language and in psychological and pedagogical issues, which can ensure effective teaching and learning. The paper aims to subject such assumptions to critical scrutiny, demonstrate that they blatantly fail to take into account the real situation in Polish education, as well as offer some tentative proposals that could enhance the quality of foreign language teacher training in our country.

Key words: foreign language teacher education, teacher knowledge base, language policy, standards for teacher education

Słowa kluczowe: kształcenie nauczycieli języków obcych, wiedza nauczyciela, polityka językowa, standardy kształcenia nauczycieli 


\section{Wstęp}

Zdobycie kwalifikacji do nauczania języka obcego w naszym kraju wiąże się z koniecznością spełnienia szeregu warunków, które zostały przede wszystkim określone w Rozporządzeniu Ministra Nauki i Szkolnictwa Wyższego z dnia 17 stycznia 2012 r. w sprawie standardów kształcenia przygotowującego do wykonywania zawodu nauczyciela. Tego typu kształcenie odbywa się głównie podczas studiów filologicznych, przy czym - w związku z nasyceniem rynku i malejącym zapotrzebowaniem na nauczycieli języka obcego, a co za tym idzie, coraz mniejszym zainteresowaniem studentów - oferta $w$ tym zakresie jest w wielu ośrodkach ograniczana, a w niektórych przypadkach dodatkowo płatna. W sytuacjach, kiedy jest ona dostępna, student uczęszcza na zajęcia z praktycznej nauki danego języka obcego, na kursy związane między innymi z językoznawstwem, wiedzą o akwizycji i nauce języka, literaturą i kulturą, jak również różnego rodzaju wykłady monograficzne, seminaria i proseminaria, a jeśli wybierze specjalizację nauczycielską, jest dodatkowo zobowiązany do zaliczenia zajęć z psychologii, pedagogiki i dydaktyki języka obcego oraz odbycia praktyk w szkole. Zakłada się więc, że po ukończeniu studiów filologicznych - czy to pierwszego, czy drugiego stopnia - i odbyciu wymaganych przepisami modułów przygotowania pedagogicznego student będzie przygotowany do nauczania danego języka obcego na kolejnych etapach edukacyjnych. Oznacza to, że powinien on wtedy posiadać niezbędną wiedzę, umiejętności i kompetencje, zarówno jeśli chodzi o ten język, jak i kwestie psychologiczno-pedagogiczne oraz dydaktyczne, które pozwolą mu skutecznie rozwijać kompetencję komunikacyjną uczniów ${ }^{1}$. Podstawowym celem niniejszego artykułu jest krytyczna ocena takich założeń, pokazanie, że nie przystają one w pełni do polskiej rzeczywistości edukacyjnej, jak również przedstawienie propozycji rozwiązań, które mogłyby się przyczynić do lepszego przygotowania nauczycieli języków do wykonywanego zawodu. W związku z tym, na samym początku omówione zostaną pokrótce kwestie związane z wiedzą i umiejętnościami nauczyciela, a następnie podjęta zostanie próba określenia najpoważniejszych problemów kształcenia nauczycieli języków obcych w Polsce. W kolejnych częściach artykułu

\footnotetext{
${ }^{1}$ Kompetencja komunikacyjna jest tu rozumiana, zgodnie z modelem zaproponowanym przez Canale i Swain (1980) oraz Canale (1983), jako wypadkowa kompetencji gramatycznej (tj. znajomości różnych podsystemów językowych), kompetencji dyskursywnej (tj. umiejętności tworzenia dłuższych tekstów), kompetencji socjolingwistycznej (tj. umiejętności używania języka odpowiednio do danego kontekstu oraz znajomości pewnych norm kulturowych) i kompetencji strategicznej (tj. zdolności pokonywania barier komunikacyjnych oraz zwiększania efektywności procesu porozumiewania się).
} 
krytycznej ocenie poddane zostaną obowiązujące standardy kształcenia nauczycieli oraz programy kształcenia na studiach filologicznych, a na zakończenie zaprezentowane zostaną konkretne rozwiązania, które mogłyby się przyczynić do lepszego przygotowania przyszłych nauczycieli języków obcych do zawodu.

\section{Wiedza i umiejętności nauczyciela}

O wiedzy i umiejętnościach nauczyciela, a także sposobach ich rozwijania napisano już bardzo wiele (np. Richards i Lockhart, 1994; Richards, 1998; Freeman, 2001; Wysocka, 2003; Freeman i Johnson, 2005; Waters, 2005; Jourdenais, 2009; Borg, 2013) i dlatego zagadnienia te zostaną tutaj przedstawione bardzo skrótowo, stanowiąc tym niemniej ważny punkt odniesienia dla rozważań w dalszej części artykułu. Choć tradycyjnie wiedza nauczyciela opisywana była w odniesieniu do dwóch oddzielnych dziedzin, tj. znajomości języka oraz znajomości sposobów jego nauczania (por. Graves, 2009), to kształcenie nauczycieli języków obcych obecnie opiera się na założeniu, że struktura tego typu wiedzy jest o wiele bardziej skomplikowana. I tak na przykład Richards (1998) proponuje model obejmujący sześć rodzajów wiedzy, które są niezbędne dla skutecznego nauczania języka obcego i dotyczą teorii nauczania, umiejętności dydaktycznych, umiejętności komunikacyjnych, znajomości przedmiotu nauczania, zdolności podejmowania decyzji podczas lekcji oraz znajomości kontekstu. Jak podkreśla Borg (2013), wspólną cechą proponowanych obecnie typologii wiedzy nauczyciela jest to, że uwzględniają one nie tylko wiedzę zewnętrznq - która ma być przekazywana studentom, a następnie przez nich przyswojona - ale także wiedzę wewnętrznq, tworzoną przez samych nauczycieli w procesie nauczania i obejmującą ich przekonania oraz osobiste teorie. Nie mniej ważne jest to, że wiedza i umiejętności nauczyciela powinny być postrzegane jako niezwykle złożony, ale też integralny system, a nie jako zbiór luźno ze sobą powiązanych komponentów, ponieważ tylko wtedy możliwe będzie skuteczne ich wykorzystanie podczas lekcji i zajęć (por. Morton i in., 2006).

Przegląd dostępnej literatury przedmiotu pozwala na określenie bardziej konkretnych rodzajów wiedzy i umiejętności (np. Roberts, 1998; Kelly i Grenfell, 2004; Farrell, 2007; Borg, 2013), które powinien posiąść nauczyciel języka obcego, ponieważ takie doprecyzowanie jest bez wątpienia przydatne, biorąc pod uwagę cele niniejszego tekstu. Nie ulega wątpliwości, że jedną z najważniejszych kompetencji nauczyciela jest bardzo dobra znajomość nauczanego języka obcego. Jak bowiem pisze Farrell (2007: 55), „poziom zaawansowania nauczyciela $w$ wielu przypadkach determinuje stopień, w jakim jest on w stanie odpowiednio stosować wiele popularnych obecnie metod nauczania, jak również to, czy potrafi dostarczyć swoim uczniom odpowiedniego modelu 
języka docelowego" (tłumaczenie autora). Lafayette (1993) stwierdza z kolei, że odpowiedni poziom zaawansowania w nauczanym języku obcym to najważniejszy element wiedzy przedmiotowej, podczas gdy Medgyes (2001) przekonuje, że podejmowanie wysiłków na rzecz lepszego opanowania tego języka to jeden z podstawowych obowiązków każdego nauczyciela. Tego typu stwierdzenia nie powinny zresztą dziwić, ponieważ ograniczona kompetencja komunikacyjna w języku docelowym ma negatywny wpływ na szereg różnych aspektów procesu dydaktycznego, takich jak: zapewnienie uczącym się odpowiedniej jakości ekspozycji na ten język, identyfikacja popełnianych przez nich błędów i odpowiednie na nie reagowanie, prowadzenie lekcji w większości w języku obcym, gotowość do improwizowania czy też odejścia od treści zawartych w podręczniku, wykorzystywanie i adaptacja materiałów autentycznych, podawanie poprawnych wyjaśnień czy w końcu użycie odpowiedniego języka klasowego (por. Farrell, 2007). Warto tutaj zaznaczyć, że dobrego opanowania języka obcego nie można utożsamiać z wiedzq o tym języku, choćby dlatego że znajomość reguł i zasad ich stosowania stanowi wiedzę eksplicytnq czy też deklaratywnq i wcale nie musi być tożsama z umiejętnością ich użycia w czasie rzeczywistym, $\mathrm{tj}$. podczas autentycznej komunikacji, co wymaga wiedzy implicytnej czy proceduralnej, a przynajmniej niezwykle wysokiego stopnia automatyzacji świadomej wiedzy eksplicytnej (por. Ellis, 2009; Pawlak, 2010). Nie oznacza to oczywiście, że wiedza o języku - nie tylko w odniesieniu do struktur gramatycznych, ale też zasad wymowy, procesów słowotwórczych, norm pragmatycznych oraz terminologii niezbędnej do ich opisu - nie jest przydatna. Wręcz przeciwnie, większość specjalistów (np. Widdowson, 2002; Andrews, 2007; Bartels, 2009; Jourdenais, 2009) podkreśla ogromną rolę takiej wiedzy w procesie dydaktycznym, podczas gdy Wright (2002) wyróżnia trzy wymiary świadomości językowej nauczycieli języka obcego, tj. świadomość językową z punktu widzenia użytkownika, analityka oraz dydaktyka. Istnieje natomiast sporo wątpliwości co do przydatności wiedzy z zakresu językoznawstwa, a także teorii i badań nad procesami nauki języka obcego, szczególnie jeśli jest ona przekazywana przyszłym nauczycielom w oderwaniu od konkretnych działań dydaktycznych i szerszego kontekstu edukacyjnego (por. Freeman i Johnson, 2005; Borg, 2013).

Oczywiście skuteczne nauczanie języka obcego wymaga także wielu innych rodzajów wiedzy i umiejętności, przy czym niektóre są specyficzne dla kształcenia językowego, a inne mają bardziej ogólny charakter i dotyczą także nauczania pozostałych przedmiotów szkolnych (np. Kelly i Grenfell, 2004; Farrell, 2007; Borg, 2013). Te pierwsze dotyczą przede wszystkim znajomości zasad dydaktyki językowej, ale też umiejętności ich wykorzystania w praktyce. Chodzi tu na przykład o sposoby nauczania podsystemów i sprawności, planowania lekcji, zarządzania dyskursem klasowym, odpowiedniego wykorzystania 
podręcznika, opracowania planu nauczania, efektywnej korekty popełnianych przez uczących się błędów, oceny stopnia opanowania różnych aspektów kompetencji komunikacyjnej w języku docelowym, tworzenia zadań komunikacyjnych, wykorzystywania materiałów autentycznych czy też prowadzenia treningu strategii uczenia się języka. Jeśli natomiast chodzi o te drugie, to związane są one z dobrą znajomością ogólnych zasad pedagogicznych, która pozwala na przykład skutecznie organizować pracę w parach lub małych grupach, efektywnie radzić sobie z niepożądanymi zachowaniami uczniów czy uwzględniać indywidualne potrzeby uczących się, zarówno tych najzdolniejszych, jak i tych obarczonych pewnymi dysfunkcjami. Do tej grupy zaliczyć też można znajomość podstawy programowej, wymagań egzaminacyjnych, kontekstu nauczania, możliwości zastosowania nowoczesnych technologii i procesów zachodzących podczas lekcji, ale także umiejętność podejmowania działań na rzecz rozwoju zawodowego. Trzeba również podkreślić, że - podobnie jak ma to miejsce w przypadku wiedzy językowej - posiadanie tego czy innego rodzaju wiedzy wcale nie musi oznaczać umiejętności jej zastosowania w praktyce, jako że - może za wyjątkiem osób obdarzonych swego rodzaju darem do nauczania - wymaga to sporego doświadczenia w wielu różnych sytuacjach. Jak więc widać, efektywne nauczanie języka obcego wiąże się z posiadaniem całego szeregu kompetencji i umiejętności, które są ze sobą ściśle powiązane i których wykształcenie na odpowiednim poziomie wymaga czasu, praktyki oraz zaangażowania. Nasuwa się zatem pytanie, w jakim stopniu kształcenie nauczycieli języka obcego w Polsce przygotowuje studentów do ich przyszłej pracy i na ile uwzględnia ono istniejącą rzeczywistość edukacyjną. Są to kwestie, które będą szerzej omówione poniżej.

\section{Wyzwania kształcenia nauczycieli języków obcych w Polsce}

Jak już wspomniano we wstępie do niniejszego artykułu, kształcenie nauczycieli języków odbywa się przede wszystkim na studiach filologicznych pierwszego i drugiego stopnia, jak również w nauczycielskich kolegiach języków obcych, które jednak wchodzą w ostatnią fazę swojego istnienia - przy czym niektóre $z$ nich są przejmowane przez wyższe uczelnie, a inne po prostu stopniowo likwidowane. W niektórych przypadkach związane jest ono również z przekwalifikowywaniem się nauczycieli, co jest przede wszystkim rezultatem malejącego zainteresowania nauką języka francuskiego, niemieckiego oraz rosyjskiego i wciąż rosnącą rolą języka angielskiego. Ważnym elementem jest też dokształcanie aktywnych zawodowo nauczycieli, które może przybierać bardzo różne formy, począwszy od jednodniowych czy kilkudniowych kursów językowych i metodycznych, a kończąc na studiach podyplomowych, na przykład 
w zakresie zintegrowanego kształcenia językowo-przedmiotowego. Trzeba tutaj jednak koniecznie zwrócić uwagę na dwie kluczowe kwestie, a mianowicie - coraz mniejsze zainteresowanie zdobyciem kwalifikacji nauczycielskich wśród studentów filologii, a także fakt, że kształcenie nauczycieli nie cieszy się często uznaniem w wielu instytucjach i jest ono traktowane jako zło konieczne. Podczas gdy to pierwsze zjawisko jest pochodną kurczącego się rynku pracy dla nauczycieli języków obcych oraz tego, że niektóre uczelnie wprowadzają dodatkowe opłaty za tego typu kształcenie, to drugie jest często emanacją całkowicie błędnego i krzywdzącego przekonania o domniemanym braku naukowości tego typu studiów. W efekcie wiele instytucji podejmuje świadomą decyzję o zaproponowaniu studentom innych, bardziej obiecujących specjalności czy specjalizacji, takich jak translatoryka czy wykorzystanie języka obcego w biznesie.

Pomimo takich negatywnych tendencji, kształcenie nauczycieli nadal stanowi bardzo ważny element studiów filologicznych, co sprawia, że warto się przez chwilę zastanowić nad licznymi problemami, z którymi musi się ono borykać. Jednym z najpoważniejszych jest bez wątpienia wciąż zmniejszająca się liczba kandydatów na studia filologiczne, włączając $w$ to tak bardzo do niedawna popularne studia anglistyczne, a co za tym idzie, coraz niższy poziom językowy, ale też coraz gorsze przygotowanie ogólne studentów i duże zróżnicowanie w tym zakresie. Innymi słowy, w wielu przypadkach na pierwszy rok studiów licencjackich bardzo często przyjmowane są osoby, które potrafią się co prawda całkiem dobrze porozumiewać w języku docelowym, ale mają elementarne braki, jeśli chodzi o znajomość podsystemów tego języka - w szczególności gramatyki. Na dodatek ich wiedza z innych dziedzin także pozostawia wiele do życzenia, a ponieważ wśród kandydatów można znaleźć oczywiście wiele osób reprezentujących dość wysoki poziom, skutkuje to niekiedy ogromnymi dysproporcjami w obrębie jednego roku czy grupy. Ten stan rzeczy wynika z jednej strony z faktu, że finansowanie wyższych uczelni jest głównie uzależnione od liczby studentów, a z drugiej - z formy i przyjętych kryteriów oceny egzaminu maturalnego z języka obcego, na którym liczy się głównie skuteczne przekazywanie informacji, a nie poprawność i spójność wypowiedzi czy przestrzeganie norm pragmatycznych i socjokulturowych. Wszystko to z kolei powoduje, że podobne problemy pojawiają się na uzupełniających studiach magisterskich, gdyż tytuł zawodowy licencjata nierzadko otrzymują osoby, które do niedawna nie miałyby zapewne na to szans. Taka a nie inna sytuacja wywiera oczywiście zdecydowanie negatywny wpływ na proces przygotowania studentów do zawodu nauczyciela. Z jednej bowiem strony niezbędne okazuje się zazwyczaj uzupełnianie braków w wiedzy eksplicytnej (tj. znajomość reguł) i - na tyle, na ile jest to realne - jej automatyzacja, a z drugiej - realizacja wielu treści merytorycznych, również tych związanych z kształceniem nauczycieli, 
jest utrudniona z uwagi na spory stopień trudności omawianych tekstów specjalistycznych i zadań wykonywanych podczas zajęć.

Coraz niższy poziom kandydatów na studia filologiczne, a potem studentów, to jednak nie jedyny problem, z którym zmierzyć się musi kształcenie nauczycieli języków obcych. Nie mniej ważną kwestią jest bowiem często niewystarczające przygotowanie osób prowadzących zajęcia wpisujące się w moduł dydaktyki językowej. Chodzi tutaj zarówno o ich kwalifikacje do prowadzenia takich zajęć, co jest wynikiem panujących ograniczeń kadrowych, jak i czasem o całkowity brak doświadczenia w pracy w państwowej szkole, niezależnie od poziomu edukacyjnego. Ten drugi problem wydaje się zresztą być o wiele istotniejszy, ponieważ trzeba sobie zadać pytanie, czy ktoś, kto nigdy nie musiał przez dłuższy czas stawiać czoła realiom pracy z dziećmi czy młodzieżą w typowych warunkach szkolnych - ze wszystkimi ich ograniczeniami - może skutecznie przygotować studentów do takich wyzwań i być przy tym przekonywującym. Uwaga ta dotyczy również osób legitymujących się najwyższymi stopniami czy też tytułami naukowymi, ponieważ znajomość nawet najnowszych teorii i wyników badań empirycznych na temat uczenia się i nauczania języków obcych - z czym zresztą często też jest problem - to stanowczo za mało, aby być dobrym nauczycielem. Kolejną trudnością jest zmieniająca się ciągle rzeczywistość edukacyjna, co powoduje, że treści proponowane podczas zajęć z dydaktyki często zupełnie nie przystają do tego, co się dzieje w klasie szkolnej. Nawet bardzo dobrze na pozór przygotowanemu absolwentowi trudno jest bowiem na przykład rozwijać autonomię, prowadzić trening strategiczny czy dbać o indywidualne potrzeby edukacyjne uczniów, jeśli tak naprawdę najważniejsze jest uczenie „pod egzamin”, a podręczniki zazwyczaj koncentrują się nie tyle na strategiach uczenia się, ile na strategiach wykonywania określonych typów zadań. Co więcej, kluczową rolę odgrywa podejmowanie działań w celu zdobycia kolejnych stopni awansu zawodowego, co tylko w niektórych sytuacjach ma związek z nauczaniem. Zwiększająca się biurokracja często ma negatywny wpływ na początkowy entuzjazm i zapał, opieka nad stażem nierzadko okazuje się fikcją, a początkujący nauczyciele nieczęsto mogą liczyć na konkretne wsparcie ze strony bardziej doświadczonych koleżanek i kolegów.

Szereg problemów dotyczy również tego, na czym koncentruje się i jak przebiega proces kształcenia nauczycieli języków obcych. Mimo że ta pierwsza kwestia jest przede wszystkim wynikiem obowiązujących standardów kształcenia nauczycieli i będzie szerzej omówiona w dalszej części artykułu, to konkretne treści - które zostają włączone do obowiązujących planów i programów studiów - zależą w dużej mierze od osób za to kształcenie odpowiedzialnych. Może się tam bowiem na przykład znaleźć szczegółowe omówienie metod nauczania języka obcego wraz z obszernym tłem historycznym, co zajmuje wiele czasu 
i ma małą wartość dla przyszłego nauczyciela, bądź bardziej praktyczne zajęcia poświęcone rozwijaniu autonomii, opracowywaniu testów czy motywowaniu uczniów, co ma szansę przyczynić się do bardziej skutecznego nauczania. Trzeba też sobie zdawać sprawę, że nawet najlepszy dobór treści nie będzie miał większego znaczenia, jeśli zajęcia te nie będą w odpowiedni, interesujący sposób prowadzone. Zbyt wiele jest przecież przypadków, kiedy ćwiczenia są w istocie wykładami, jedynym zadaniem studentów jest wyrecytowanie definicji czy list z nie zawsze aktualnych źródeł, a czasami podstawową wykorzystywaną przez prowadzącego techniką są prezentacje studentów, co w zasadzie całkowicie eliminuje potrzebę ciekawego przygotowania zajęć. Występują też spore trudności ze skuteczną organizacją praktyk, zarówno po stronie uczelni - co jest związane z brakiem odpowiedniego nadzoru i sposobności omawiania prowadzonych zajęć - jak i szkół, w których praktyki te się odbywają, ponieważ praktykanci są często postrzegani jako zło konieczne, a opieka nad nimi pozostawia wiele do życzenia. W końcu, wiele problemów wynika z faktu, że moduł kształcenia nauczycieli jest opcjonalny, a co za tym idzie, jego zaliczenie nie jest niezbędne do zaliczenia danego semestru czy roku, a nawet ukończenia toku studiów - o ile student spełni inne wymagania i zdobędzie wymaganą w cyklu kształcenia liczbę punktów ECTS. Taka sytuacja powoduje, że wielu studentów nie traktuje poważnie zajęć wchodzących w skład bloku pedagogicznego, uważając że zaliczenie im się najzwyczajniej w świecie należy. Wykładowcy z kolei unikają tworzenia nadmiernych problemów z obawy o to, że nazbyt wysokie wymagania spowodują, iż w kolejnym roku akademickim może zabraknąć osób, które byłyby zainteresowane uzyskaniem kwalifikacji pedagogicznych, a to może stanowić realne zagrożenia dla ich miejsca pracy.

\section{Słabości standardów kształcenia nauczycieli i programów nauczania}

Jak wspomniano we wstępie do niniejszego artykułu, programy kształcenia nauczycieli - w tym te dotyczące kształcenia nauczycieli języków obcych - powinny uwzględniać standardy określone w Rozporządzeniu Ministra Nauki i Szkolnictwa Wyższego z dnia 17 stycznia 2012 r. Dokument ten stanowi, że w celu zapewniania realizacji ogólnych i szczegółowych efektów kształcenia, przygotowanie to musi obejmować następujące moduły ${ }^{2}$ : (1) przygotowanie merytoryczne w zakresie określonego przedmiotu -zgodnie z opisem efektów kształcenia dla realizowanego kierunku studiów; w przypadku języka obcego

\footnotetext{
2 Ponieważ niniejszy artykuł koncentruje się na nauczaniu języka obcego jako pierwszego przedmiotu, wymienione są tu jedynie moduły 1-3, podczas gdy moduły 4 (przygotowanie do nauczania kolejnego przedmiotu) oraz 5 (przygotowanie w zakresie pedagogiki specjalnej) zostały pominięte.
} 
oznacza to również osiągnięcie poziomu C1 według Europejskiego systemu opisu kształcenia językowego, (2) przygotowanie w zakresie pedagogicznopsychologicznym, zarówno o charakterze ogólnym (90 godzin), jak i w odniesieniu do danego etapu edukacyjnego ( 60 godzin) oraz praktykę pedagogiczną (30 godzin) i (3) przygotowanie w zakresie dydaktycznym, które obejmuje podstawy dydaktyki (30 godzin), dydaktykę danego przedmiotu na danym etapie lub etapach edukacyjnych (90 godzin), jak również praktykę pedagogiczną (120 godzin). Tego typu kształcenie powinno też uwzględniać możliwość osiągnięcia efektów kształcenia związanych z bezpieczeństwem i higieną pracy, emisją głosu i wykorzystaniem technologii informacyjnej. Zastrzega się też, że realizacja Modułu 2 i 3 powinna trwać łącznie nie mniej niż trzy semestry, przy czym musi być zachowana kolejność ich realizacji.

Choć dokument precyzuje treści kształcenia, które powinny być uwzględnione podczas realizacji każdego z modułów, w większości przypadków są one przedstawione dość ogólnie, dając uczelniom sporą swobodę w kwestii ich doboru oraz realizacji. I tak na przykład, jeśli chodzi o dydaktykę nauczania określonego przedmiotu, tj. Moduł 3, niezależnie od etapu edukacyjnego znajdujemy między innymi odniesienia do zapisów podstawy programowej, podmiotowości i pełnomocności ucznia, ról pełnionych przez nauczyciela, metod i zasad nauczania, form pracy, sposobów organizacji lekcji, trudności uczenia się czy uwzględnienia potrzeb i możliwości ucznia. Jak więc widać, nie bierze się tutaj w ogóle pod uwagę specyfiki dydaktyki językowej, a dobór realizowanych treści zależy w zasadzie tylko i wyłącznie od osób nadzorujących kształcenie nauczycieli, a w wielu przypadkach spora swoboda $w$ tym zakresie pozostawiona jest prowadzącym. Jeszcze trudniej jest uwzględnić tę specyfikę w przypadku Modułu 2, obejmującego przygotowanie psychologiczno-pedagogiczne. Dzieje się tak dlatego, że na przykład zagadnienia związane z zawodem nauczyciela języka obcego czy komunikowania się w klasie językowej mają swoją specyfikę, często zupełnie odmienną niż w przypadku innych przedmiotów (ogólne przygotowanie psychologiczno-pedagogiczne), a omówienie form aktywności młodzieży i kontaktów społecznych ucznia stałoby się bardziej przydatne, gdyby odnosiło się również do nauczania języka obcego (przygotowanie związane $z$ danym etapem edukacyjnym).

Trzeba także wyraźnie zaznaczyć, że kształcenie pedagogiczne na studiach pierwszego stopnia w zakresie danego przedmiotu - również w odniesieniu do nauczania języka obcego - daje bardzo ograniczone uprawnienia. Na 4 stronie dokumentu możemy bowiem przeczytać, że „Kształcenie na studiach pierwszego stopnia obejmuje wyłącznie przygotowanie do wykonywania zawodu nauczyciela w przedszkolach i szkołach podstawowych, a na studiach drugiego stopnia i jednolitych studiach magisterskich - do pracy we wszystkich typach 
szkół i rodzajach placówek". Wydaje się, że zapis ten należy jednak interpretować, biorąc pod uwagę następujące stwierdzenie, które zamieszczono na stronie 6: „Przygotowanie merytoryczne do wykonywania zawodu nauczyciela w przedszkolu (edukacja przedszkolna) oraz do nauczania w klasach I-III szkoły podstawowej (I etap edukacyjny) jest realizowane na studiach w zakresie pedagogiki lub innych zapewniających przygotowanie do pracy w obszarze edukacji elementarnej (...)". Choć brak jednoznacznej interpretacji tych zapisów, to należy przyjąć, że po ukończeniu studiów licencjackich absolwent filologii obcej posiada jedynie uprawnienia do nauczania danego języka obcego w klasach IV-VI szkoły podstawowej, a więc tylko na II etapie edukacyjnym, ponieważ nauczanie tego języka w przedszkolu i w klasach I-III szkoły podstawowej wymaga dodatkowych kwalifikacji, w zasadzie tożsamych z tymi, jakie otrzymują absolwenci studiów pedagogicznych. Chociaż wiele zależy w tym przypadku od dyrektorów przedszkoli i szkół podstawowych, to jest to kolejne bardzo istotne ograniczenie, które w znacznym stopniu utrudnia znalezienie pracy w zawodzie.

Nawet bardzo pobieżna analiza przedstawionych powyżej przepisów musi doprowadzić specjalistę w zakresie uczenia się i nauczania języków obcych do przekonania, że są one w wielu przypadkach ułomne, nie przystają do naszej rzeczywistości edukacyjnej i nie mogą zapewnić odpowiedniego przygotowania nauczyciela języka obcego. Po pierwsze, trudno się oprzeć wrażeniu, że pierwszoplanową rolę przy opracowaniu obowiązujących zapisów odegrali psycholodzy oraz pedagodzy i że po prostu zabrakło rzetelnej konsultacji z naukowcami specjalizującymi się w dydaktyce językowej, a także z całym środowiskiem odpowiedzialnym za kształcenie nauczycieli języków obcych. W rezultacie na dydaktykę w zakresie nauczania języka obcego przeznaczono jedynie 90 godzin, a to stanowczo za mało, aby wyposażyć studentów choćby w te najbardziej niezbędne rodzaje wiedzy, narzędzia i umiejętności, o których była mowa w sekcji 2. niniejszego artykułu. Nasuwa się tutaj pytanie, czy w opinii autorów dokumentu w ogóle możliwe jest w tak krótkim czasie zapoznanie studentów z tak kluczowymi zagadnieniami, jak nauczanie wszystkich podsystemów i sprawności oraz ich integracja, planowanie lekcji, dokonywanie oceny i adaptacji podręczników, opracowywanie programów nauczania, skuteczna korekta błędów językowych czy też konstruowanie testów. Trzeba przecież pamiętać, że poza podaniem pewnych zasad, konieczne jest zapewnienie licznych możliwości ich implementacji w praktyce, a poza tym studenci muszą się zapoznać - przynajmniej w ogólnych zarysach - z podstawowymi teoriami dotyczącymi uczenia się języka ojczystego i języków obcych, rolą różnic indywidualnych w nauce języka obcego itp. W takiej sytuacji można często jedynie wspomnieć o tym, jak stymulować postawy i zachowania o charakterze autonomicznym, rozwijać kompetencję interkulturową, skutecznie radzić sobie 
z problemami z dyscypliną czy też uwzględniać indywidualne potrzeby uczniów - zarówno tych bardzo zdolnych, jak i tych obdarzonych pewnymi dysfunkcjami. Dlatego też konieczne wydaje się poszerzenie tego modułu, a ponieważ nie da się bez końca zwiększać liczby godzin, należałoby się poważnie zastanowić, czy nie powinno się to odbyć w jakimś zakresie kosztem modułu psychologiczno-pedagogicznego. Nie mniej ważną kwestią jest adekwatność treści nauczania dotyczących poszczególnych modułów, które - jak pokazano powyżej - często nie uwzględniają w odpowiednim stopniu specyfiki nauczania języka obcego. W końcu, ogromne wątpliwości budzi także aż tak daleko idące ograniczenie uprawnień w przypadku absolwentów studiów pierwszego stopnia. Można bowiem zadać pytanie, czy w przedszkolu i w klasach I-III szkoły podstawowej do skutecznego nauczania języka obcego nie wystarczy jego dobra znajomość i niezbędne przygotowanie pedagogiczne. $Z$ kolei, skoro absolwenci studiów licencjackich mają się legitymować znajomością języka obcego na poziomie $\mathrm{C} 1$, to dlaczego górnym pułapem, na którym mogą prowadzić zajęcia, jest III etap edukacyjny, a więc szkoły gimnazjalne. Wszystko to jasno pokazuje, że obecne standardy kształcenia nauczycieli wymagają sporych modyfikacji, o czym będzie mowa w ostatniej części artykułu.

Jest rzeczą oczywistą, że realizowane na kierunkach filologicznych programy kształcenia nauczycieli muszą uwzględniać przedstawione powyżej standardy, choć istnieją między nimi spore różnice w odniesieniu do poszczególnych modułów. Niezależnie od ośrodka i danej filologii obcej najwięcej podobieństw można znaleźć zapewne w przypadku Modułu 1, czyli przygotowania merytorycznego. Pomimo pewnych dysproporcji w konkretnej liczbie godzin czy stosowanym nazewnictwie przedmiotów, uwzględnia ono w dużej mierze obowiązujące do niedawna standardy kształcenia dla kierunku filologia i obejmuje zajęcia z praktycznej nauki języka obcego, wiedzy o akwizycji i nauce języka, językoznawstwa, językoznawstwa stosowanego, literaturoznawstwa czy też kulturoznawstwa, jak również ściśle związane z tymi dziedzinami wykłady monograficzne, seminaria, seminaria uzupełniające i proseminaria. Większą różnorodność można natomiast dostrzec w Modułach 2 i 3, nie tylko na poziomie przedmiotów, które są w ramach nich prowadzone, ale także - z uwagi na charakter opisanych wyżej standardów - realizowanych treści, ponieważ stanowią one często odzwierciedlenie zainteresowań samych wykładowców. Różnica polega jednak na tym, że o ile przygotowanie o charakterze psychologiczno-pedagogicznym jest najczęściej realizowane w języku polskim oraz zazwyczaj nie uwzględnia specyfiki uczenia się i nauczania języków obcych, o tyle kształcenie w zakresie dydaktyki językowej odbywa się w większości przypadków w języku docelowym i, choć jest ono nierzadko niedoskonałe i koncentruje się na pewnych zagadnieniach kosztem innych, na pewno ma 
bardziej bezpośrednie przełożenia na to, co się dzieje w klasie językowej. Warto w tym miejscu wspomnieć, że elementy przygotowania pedagogicznego są również często realizowane na seminariach, proseminariach, seminariach przedmiotowych czy wykładach monograficznych, dających szansę bardziej szczegółowego przedstawienia zagadnień, na które po prostu nie wystarcza czasu podczas zajęć z dydaktyki języka obcego.

Oczywiście sporo problemów nie wynika jedynie z obowiązujących standardów kształcenia nauczycieli, lecz ma swoje źródło w bardziej ogólnych tendencjach i zjawiskach - o których była szerzej mowa w poprzedniej części artykułu takich jak chociażby obniżający się poziom językowy studentów. Sprawia to, że wykładowca staje na przykład przed dylematem, w jakim języku ma prowadzić zajęcia z dydaktyki przedmiotowej (tj. ojczystym czy docelowym). Inną kwestią jest uwzględnienie specyfiki nauczania języka na danym etapie edukacyjnym, ponieważ choć takie rozróżnienie jest wyeksponowane w obowiązujących przepisach, pewne zasady są często omawiane w bardziej uogólniony sposób - czy to z uwagi na ograniczenia czasowe, czy na doświadczenia i kompetencje konkretnego wykładowcy. Ogromnym problemem jest w końcu brak odpowiednich podręczników metodycznych, takich które z jednej strony uwzględniałyby najnowsze propozycje teoretyczne i wyniki badań empirycznych, a z drugiej były dostosowane do specyfiki polskiego kontekstu edukacyjnego, a nie przeznaczone dla osób pracujących w klasach wielojęzycznych, często w sytuacji, gdzie uczący się mają nieograniczony dostęp do języka docelowego poza szkołą.

\section{Propozycje rozwiązań}

O problemach kształcenia nauczycieli języków obcych w Polsce napisano już wiele tekstów, ale w większości przypadków ich autorzy wskazują na istniejące niedoskonałości i unikają proponowania konkretnych rozwiązań. Choć jest to zapewne podyktowane brakiem wiary $w$ to, że tego typu propozycje zostaną wzięte pod uwagę przez decydentów i przyczynią się do modyfikacji obowiązujących przepisów oraz zmiany otaczającej nas rzeczywistości, to być może takie postulaty są właśnie potrzebne, aby zainicjować dyskusję i stworzyć pewną alternatywę dla istniejącego stanu rzeczy. Biorąc pod uwagę rozważania zawarte w niniejszym artykule, można wskazać szereg działań, które należałoby podjąć, aby z jednej strony podnieść jakość kształcenia nauczycieli języków obcych, a co za tym idzie, zwiększyć skuteczność nauczania tych języków na różnych etapach edukacyjnych, a z drugiej w większym stopniu dostosować tego typu kształcenie do obecnych realiów. Propozycje te przedstawiają się następująco:

- opracowanie odrębnych standardów kształcenia dla nauczycieli języków obcych; 
- prowadzenie zajęć z pedagogiki i psychologii w języku obcym przy uwzględnieniu specyfiki nauki tego języka;

- zwiększenie liczby zajęć z dydaktyki językowej, które uwzględniałyby najbardziej istotne zagadnienia (np. trening strategii uczenia się, specjalne potrzeby edukacyjne, motywowanie uczących się itp.);

- podkreślenie ogólnego charakteru pewnych zasad dydaktyki językowej, a następnie jedynie ich uzupełnianie w odniesieniu do poszczególnych etapów edukacyjnych;

- przyznanie absolwentom studiów pierwszego stopnia wyraźnie określonych, szerszych uprawnień, tak aby mogli oni uczyć języka obcego na I, II i III etapie edukacyjnym;

- ściślejsze powiązanie zajęć z dydaktyki języka obcego z zajęciami poświęconymi wiedzy o akwizycji i nauce języka;

- zwiększenie praktycznego wymiaru zajęć z dydaktyki języka obcego;

- zwiększenie wymiaru praktyk pedagogicznych, lepsze ich monitorowanie i ściślejsza współpraca ze szkołami w tym zakresie;

- zaangażowanie wyższych uczelni w procedurę uzyskiwania kolejnych stopni awansu zawodowego przez nauczycieli języka obcego;

- wprowadzenie obligatoryjnych, periodycznych egzaminów językowych oraz kursów metodycznych dla nauczycieli;

- organizowanie w szkołach oraz na uczelniach cyklicznych spotkań ze specjalistami dydaktyki językowej w celu pełniejszego powiązania teorii i wyników badań z codzienną praktyką dydaktyczną.

Choć realizacja większości zaproponowanych rozwiązań wymagałaby zmian obowiązujących aktów prawnych, wiązałaby się z dodatkowymi nakładami finansowymi i z całą pewnością spotkałaby się z niechęcią pewnych środowisk, niektóre z powyższych postulatów są możliwe do realizacji praktycznie od zaraz. Wiele zależy tutaj jednak od osób odpowiedzialnych za kształcenie nauczycieli języków obcych w wyższych uczelniach, a wydaje się, że to właśnie stamtąd powinien nadejść impuls do stopniowego wprowadzania jakże potrzebnych zmian w tym zakresie.

\section{BIBLIOGRAFIA}

Andrews, S. 2007. Teacher language awareness. Cambridge: Cambridge University Press. Bartels, N. 2009. „Knowledge about language” (w) The Cambridge guide to second language teacher education (red. A. Burns, J. C. Richards). Cambridge: Cambridge University Press: 125-134.

Borg, S. 2013. „Language teacher education” (w) The Routledge handbook of applied linguistics (red. J. Simpson). London and New York: Routledge: 215-228. 
Canale, M. 1983. „From communicative competence to communicative language pedagogy" (w) Language and communication (red. J. C. Richards, R. W. Schmidt). London: Longman: 2-27.

Canale, M., Swain, M. 1980. „Theoretical bases of communicative approaches to second language teaching and testing" Applied Linguistics 1: 1-47.

Coste, D., North, B., Sheils, J. i Trim, J. 2003. Europejski system opisu kształcenia językowego: uczenie się, nauczanie, ocenianie. Warszawa: Wydawnictwa Centralnego Ośrodka Kształcenia Nauczycieli.

Ellis, R. 2009. „Implicit and explicit learning, knowledge and instruction” (w) Implicit and explicit knowledge in second language learning, testing and teaching (red. R. Ellis, S. Loewen, C. Elder, R. Erlam, J. Philp i H. Reinders). Bristol: Multilingual Matters: 3-25.

Farrell, T. S. C. 2007. Reflective language teaching: From research to practice. London: Continuum.

Freeman, D. 2001. „Second language teacher education” (w) The Cambridge guide to teaching English to teachers of other languages (red. R. Carter, D. Nunan). Cambridge: Cambridge University Press: 72-79.

Freeman, D., Johnson, K. E. 2005. „Towards linking teacher knowledge and student learning" (w) Second language teacher education: International perspectives (red. D. Tedick). Mahwah, NJ. Lawrence Erlbaum: 73-95.

Graves, K. 2009. „The curriculum of second language teacher education” (w) The Cambridge guide to second language teacher education (red. A. Burns, J. C. Richards). Cambridge: Cambridge University Press: 115-125.

Jourdenais, R. 2009. „Language teacher education” (w) The handbook of language teaching (red. M. H. Long, C. J. Doughty). Oxford: Wiley-Blackwell: 647-658.

Kelly, M., Grenfell, M. 2004. European profile for language teacher education. A frame of reference. Southampton: University of Southampton.

Lafayette, R. 1993. „Subject matter content: What every foreign language teacher needs to know" (w) Developing language teachers for a changing world (red. G. Guntermann). Illinois: National Textbook Company: 124-158.

Medgyes, P. 2001. „When the teacher is a non-native speaker" (w) Teaching English as a second or foreign language (red. M. Celce-Murcia). Boston: Heinle \& Heinle: 415-427.

Morton, T., Maguire, T. i Baynham, M. 2006. A literature review of research on teacher education in adult literacy, numeracy and ESOL. London: NRDC.

Pawlak, M. 2010. „Problemy pomiaru wiedzy językowej”. Neofilolog 35: 9-22.

Richards, J. C. 1998. Beyond training. Cambridge: Cambridge University Press.

Richards, J. C., Lockhart, C. 1994. Reflective teaching in second language classrooms. Cambridge: Cambridge University Press.

Rozporządzenie Ministra Nauki i Szkolnictwa Wyższego z dnia 17 stycznia 2012 r. w sprawie standardów kształcenia przygotowującego do wykonywania zawodu nauczyciela.

Roberts, J. 1998. Language teacher education. London: Arnold.

Waters, A. 2005. „Expertise in teacher education” (w) Expertise in second language learning and teaching (red. K. Johnson). New York: Palgrave Macmillan: 201-229. 
Studia filologiczne, przygotowanie do zawodu nauczyciela a wyzwania codzienności

Widdowson, H. 2002. "Language teaching: Defining the subject” (w) Language in language teacher education (red. T. Trappes-Lomax). Amsterdam: John Benjamins: 67-81.

Wright, T. 2002. „Doing language awareness: Issues for language study in language teacher education" ( $\mathrm{w}$ ) Language in language teacher education (red. T. TrappesLomax). Amsterdam: John Benjamins: 115-130.

Wysocka, M. 2003. Profesjonalizm w nauczaniu języków obcych. Katowice: Wydawnictwo Uniwersytetu Śląskiego. 